\title{
Effect of nozzle type and pressure on spray droplet characteristics
}

\author{
Efecto del tipo de boquilla y la presión sobre \\ las características de las gotas de pulverización \\ Rodrigo Nogueira Martins ${ }^{1 *}$, Hugo Marcus Fialho e Moraes ${ }^{1}$, Márcio Alexandre Moreira de Freitas ${ }^{1}$, \\ Alessandro da Costa Lima ${ }^{2}$, Marconi Ribeiro Furtado Junior ${ }^{1}$
}

\begin{abstract}
Spray nozzles can be considered the most important items of sprayers, and the ideal nozzle-pressure combination plays a major role in the effectiveness of pest control in the field. Spray nozzle manufacturers often develop, and make new alternatives available on the market; however, studies are always important to verify the behavior of these new technologies concerning the spectrum of the droplets produced. Therefore, the present study aimed to evaluate the spectrum of droplets generated by four spray nozzles (FC3D 100-02; VP 110-02; TR 110-02 and TT 110-02) under different working pressures (138, 207, 276, 345, and $414 \mathrm{kPa})$. For this, a factorial scheme in a completely randomized design with four replications was used. The parameters evaluated were volumetric median diameter (VMD), relative amplitude (Span), and the percentage of droplets with a diameter smaller than $100 \mu \mathrm{m}(<100 \mu \mathrm{m})$. The spray nozzles models and the working pressure had a direct effect on the droplet size. Furthermore, there were no significant differences between the TR 110-02 and VP 110-02 models for the percentage of spray volume containing droplets $<100 \mu \mathrm{m}$ neither for the VMD. Lastly, the increase of pressure resulted in an increasing linear effect on the Span index for the FC3D 100-02 nozzle.

Keywords: droplet size spectrum, application technology, spraying, nozzles.
\end{abstract}

\section{RESUMEN}

Las boquillas de pulverización pueden considerarse los elementos más importantes de los pulverizadores y la combinación ideal de estas y su presión juega un papel esencial en la efectividad del control de plagas en el campo. Los fabricantes de boquillas de pulverización a menudo desarrollan y ofrecen nuevas alternativas en el mercado; sin embargo, los estudios siempre son fundamentales para verificar el comportamiento de estas tecnologías en relación con el espectro de las gotas producidas. Por lo tanto, el presente trabajo tuvo por objetivo evaluar el espectro de gotas generadas por cuatro boquillas de pulverización (FC3D 100-02; VP 110-02, TR 110-02 y TT 110-02) bajo diferentes presiones de trabajo (138, 207, 276, 345 y 414 kPa). Se utilizó un esquema factorial fue en un diseño completamente al azar, con cuatro repeticiones. Los parámetros evaluados fueron el diámetro de la mediana volumétrica (DMV), la amplitud relativa (Span) y el porcentaje de gotas con un diámetro menor a $100 \mu m(<100$ $\mu \mathrm{m})$. Las boquillas de pulverización y la presión de trabajo tuvieron un efecto directo sobre el tamaño de las gotas. Además, no hubo diferencias significativas entre TR 110-02 y VP 110-02 para el porcentaje de volumen de pulverización que contiene gotas $<100 \mu m$, ni para el DMV. Por último, el aumento de presión resultó en efecto linear creciente en el índice de Span para la boquilla FC3D 100-02.

Palabras clave: espectro de gotas, tecnologia de aplicación, pulverización, boquillas.

\section{Introduction}

The application of pesticides is a complex task, involving a series of factors, such as diversity of equipment and spraying methods, differences between chemicals, disparities in the skill of operators, uncontrollable weather conditions, worker safety, environmental legislation, spray volume, crop canopy size and density and the cost-benefit ratio of pesticide applications (Alvarenga et al., 2013). Pesticides are generally applied as a spray covering all or part of the target (e.g., an insect, leaves, or other plant parts).

The control of diseases, insects, and weeds in the production of crops is directly linked to the technology of application of pesticides (Cunha et al., 2016), and the spray nozzle is particularly important because it is responsible for the production and

1 Department of Agricultural Engineering, Federal University of Viçosa (UFV), Viçosa, Brazil.

2 Department of Agronomy, Federal University of Viçosa (UFV), Viçosa, Brazil.

* Corresponding author: rodrigo.n.martins@ufv.br

Fecha de Recepción: 30 de Octubre, 2020.

Fecha de Aceptación: 27 de Diciembre, 2020. 
distribution of droplets, which can be considered the most important item of sprayers (Marangoni Junior and da Costa Ferreira, 2019).

Factors such as the volume of application, spray nozzles used, and working pressure play a significant role in the effectiveness of pest control in the field (Dorneles et al., 2019). Spray nozzles that provide a more homogeneous droplet spectrum provide a higher quality application. For this, it is necessary to know the technical characteristics of the spray nozzles, aiming to select those that produce droplets of the appropriate size under certain working pressure.

Droplet size is affected by nozzle type and orifice size, liquid properties, and spray pressure (Nuyttens et al., 2009). The operating pressure of sprayers affects the droplet size in the direction of the higher the pressure and the smaller the droplet size (Marangoni Junior and da Costa Ferreira, 2019). However, the size of the droplets produced does not always follow a uniform distribution, and droplets of different sizes can be produced by a single nozzle.

The main parameters for determining the droplets population are the volumetric median diameter (VMD), the relative amplitude (Span), and the percentage of droplets with a diameter smaller than $100 \mu \mathrm{m}$ (Viana et al., 2010). According to Arvidsson et al. (2011), there is a correlation between the volume fraction of droplets $\leq 100 \mu \mathrm{m}$ in the spray from different kinds of nozzles and the total drift and the volume fraction of droplets $\leq 100 \mu \mathrm{m}$ is a better predictor of the drift hazard than the VMD.

The spray droplet size classes according to the American Society of Agricultural and Biological Engineers (ASABE) standard are: Extremely-Fine (EF), Very-Fine (VF), Fine (F), Medium (M), Coarse (C), Very-Coarse (VC), Extremely-Coarse (EC), and Ultra-Coarse (UC) (Ferguson et al., 2018). The most suitable droplet size will depend on each situation. In general, small droplets allow greater coverage on the target, while large droplets are less prone to drift.

The selection of spray nozzles is of great importance, as it is a determining factor of the amount applied per area, the uniformity of application, the coverage, and the potential risk of drift (Martini et al., 2015). Additionally, it is necessary to be aware of the weather conditions to ensure that spraying the pesticide is effective and efficient (Maciel et al., 2016). The ideal nozzle-pressure combination will maximize spray efficiency for transferring and depositing a lethal dose to the target (Nuyttens et al., 2007).

Spray nozzle manufacturers often develop and make new alternatives available on the market, such as the FC3D nozzle (Hypro/Pentair), in an attempt to increase the efficiency of applications. However, studies are always important to verify the behavior of these new technologies concerning the spectrum of the droplets produced. Therefore, the present study aimed to evaluate the spectrum of droplets generated by four spray nozzles under different working pressures.

\section{Material and Methods}

The study was carried out at the Department of Agricultural Engineering of the Federal University of Viçosa, Viçosa, Minas Gerais State, Brazil. A 4 x 5 factorial scheme comprising four nozzles models and five working pressures was used in a completely randomized design, with four replications. The following nozzle models were used: FC3D 100-02 (Hypro/Pentair); VP 110-02 (Hypro/Pentair); TR 110-02 (Hypro/Pentair); and TT 110-02 (Teejet/ Spray Systems). The above-mentioned nozzles can be used under the working pressure range from 100 to $500 \mathrm{kpa}$, according to the manufacturer's recommendations. In this sense, the operating pressures used to obtain the droplet spectrum were $138,207,276,345$, and $414 \mathrm{kPa}$.

The droplets were analyzed using a laser particle analyzer (model Spraytech, Malvern Instruments Ltd., Worcestershire, UK). This device has a focal length of $750 \mathrm{~mm}$ and uses a laser diffraction technique for measuring the size of the sprayed droplets. Moreover, it measures the intensity of light that is scattered as a laser beam passes through a sprayed jet (Maciel et al., 2016). Then, the data are analyzed to obtain the droplet parameters. The particle analyzer was configured to count droplets ranging from 0.10 to $2,500 \mu \mathrm{m}$, with an acquisition rate of $2.5 \mathrm{kHz}$ and a reading time of $1.5 \mathrm{~s}$. The study was carried out respecting the psychrometric conditions recommended by ISO 5682.1 (ISO, 2017). Thus, the analyzes were performed only at temperatures below $25^{\circ} \mathrm{C}$ and the relative humidity above $50 \%$, according to guidance (Maciel et al., 2017).

Prior to the analyses, the nozzles were installed in a spray boom at $0.50 \mathrm{~m}$ from the laser beam. The 
structure used had an electric motor installed at the end of the boom. This motor allowed a complete revolving of the boom, ensuring a complete analysis of the jet emitted from the nozzles. A detailed description of the technical characteristics of the structure used is presented by Sasaki et al. (2016). Finally, the droplet spectrum analysis included the following parameters: the volumetric median diameter (VMD), the percentage of spray volume containing droplets smaller than $100 \mu \mathrm{m}$ $(\mathrm{V}<100(\%))$, and the relative amplitude (Span).

For the statistical analyses, the droplet spectrum parameters of the nozzles were submitted to regression analysis. The models were chosen based on the significance of the regression coefficients using the t-test at a 5\% probability level and the coefficient of determination $\left(\mathrm{R}^{2}\right)$. On the other hand, the comparison between nozzles was assessed using an analysis of variance (ANOVA) and, when significant differences were found, the average values were compared by the Tukey at $5 \%$ probability test.

\section{Results and Discussion}

During the experiments, the temperature inside the laboratory varied from 20 to $24{ }^{\circ} \mathrm{C}$, and the relative humidity was always above $60 \%$. Also, all analyses were carried out in the absence of wind. The VMD values from the four nozzles models are presented in Table 1. Even though all nozzles models had a nominal flow rate of $0.2 \mathrm{gal} \mathrm{min}^{-1}$, the highest VMD values were presented by the TT 110-02, followed by the FC3D 100-02 nozzle. Furthermore, the TR 110-02 and VP 110-02 models showed no significant difference among them, regardless of the pressure used. These results were expected due to the design and engineering inserted in each nozzle model, which allows the formation of different droplet sizes, even from nozzles with the same nominal flow rate.

The technical specifications with the droplet size ranges are found in the spray nozzle manufacturers' catalogs; however, these specifications may change according to the physical characteristics of liquid applied, environmental conditions, machinery characteristics, and engineering, the methodology used, among others (Lopes and Reis, 2020). In this sense, knowing the technical characteristics of the spray nozzles is fundamental for their correct selection, which makes it possible to carry out efficient and environmentally safe applications (Cunha et al. 2010).

The nozzle TT 110-02 presented no significance for any of the regression models tested. On the other hand, the FC3D 100-02, VP 110-02, and TR 110-02 models showed a decrease in the VMD with increased pressure (Figure 1). The droplet size produced by the spray nozzle can help in the success of pest control in the crop; however, regardless of the model used, the difficulty of reaching the leaves on the lower third of the plant is always evident (Cunha et al., 2011). Increasing the efficacy of pesticide treatments requires the utilization of optimally sized sprays for a given situation, and the energy contained in the droplets is directly responsible for their ability to penetrate the canopy (Cunha et al., 2016; Ferguson et al., 2018). In addition, for most nozzle designs, the increase in the spray liquid pressure results in a finer spray but also increases the velocity of droplets, which decreases drift distances (Nuyttens et al., 2009).

The percentage of the sprayed volume composed of droplets smaller than $100 \mu \mathrm{m}$ diameter indicates the drift risk (Cunha et al., 2016). The VP 110-02 and

Table 1. Volumetric median diameter (VMD, $\mu \mathrm{m})$ of spray nozzles obtained with the laser particle analyzer in the pressures of 138, 207, 276, 345, and $414 \mathrm{kPa}$.

\begin{tabular}{|c|c|c|c|c|c|c|}
\hline \multirow{3}{*}{ Equipment } & & \multicolumn{5}{|c|}{ VMD $(\mu \mathrm{m})$} \\
\hline & \multirow[b]{2}{*}{ Nozzle } & \multicolumn{5}{|c|}{ Pressure $(\mathrm{kPa})$} \\
\hline & & 138 & 207 & 276 & 345 & 414 \\
\hline \multirow{4}{*}{ Spraytec } & FC3D 100-02 & $397.02^{\mathrm{a}}$ & $285.27^{b}$ & $264.84^{\mathrm{b}}$ & $205.90^{\mathrm{b}}$ & $192.75^{b}$ \\
\hline & VP 110-02 & $264.47^{b}$ & $182.37^{\mathrm{c}}$ & $152.75^{\mathrm{c}}$ & $141.92^{\mathrm{b}}$ & $134.17^{\mathrm{b}}$ \\
\hline & TR $110-02$ & $303.65^{\mathrm{b}}$ & $218.85^{\mathrm{bc}}$ & $165.72^{c}$ & $146.87^{\mathrm{b}}$ & $142.30^{\mathrm{b}}$ \\
\hline & TT $110-02$ & $440.70^{\mathrm{a}}$ & $388.35^{\mathrm{a}}$ & $466.32^{\mathrm{a}}$ & $367.65^{\mathrm{a}}$ & $378.27^{\mathrm{a}}$ \\
\hline
\end{tabular}

Values followed by the same letter within the same column are not significantly different at $5 \%$ probability $(\mathrm{p}<0.05)$. 

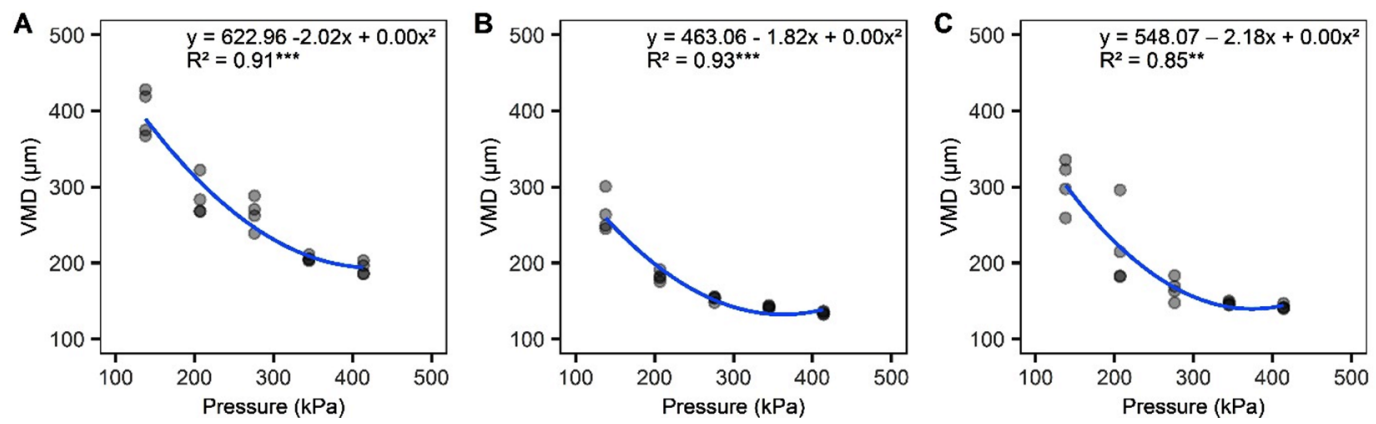

Figure 1. Estimates of the volumetric median diameter as function of the working pressure: (A) FC3D 100-02; (B) VP 11002; and (C) TR 110-02.

TR 110-02 nozzles presented values greater than 20\% when used at $345 \mathrm{kPa}$, indicating a high risk of drift if used under critical environmental conditions (e.g., high temperature and low relative humidity). On the other hand, the TT 110-02 model presented values below $6 \%$ for this parameter in all working pressures (Table 2). In previous studies, after evaluating the spectrum of flat fan nozzles, the authors reported values greater than $20 \%(\mathrm{~V}<100(\%))$ when using pressures of $300 \mathrm{kPa}$ (Balsari et al., 2017), and $400 \mathrm{kPa}$ (Camara et al., 2008).

Overall, except for the TT 110-02 model that presented no significance for the regression coefficients, all other spray nozzles were adjusted to a linear model, in which the droplet percentage under $100 \mu \mathrm{m}$ increased linearly with the increase of pressure (Figure 2). The higher working pressure resulted in an increase of drift from the standard flat fan nozzle AXI 11002 (Gandolfo et al., 2014). Applications with values below $15 \%$ of the sprayed volume composed of droplets with a diameter smaller than $100 \mu \mathrm{m}$ seem to be more suitable for a safer application (Cunha et al., 2003; Lopes and Reis, 2020).

Thus, reducing the working pressure can be a possible solution for minimizing drift since it reduces the fraction of droplets smaller and equal to $100 \mu \mathrm{m}$. However, the pressures established by the spray nozzle manufacturer must be respected since when using pressures outside of the established range, the spray opening angle can be changed, which will compromise the quality of the application (Arvidsson et al., 2011; Maciel et al., 2017).

In phytosanitary treatments performed with pesticides aimed at controlling insects and fungi, smaller droplets are preferred. Generally, the spray nozzles that produce fine droplets provide good surface coverage and higher uniformity of spray distribution, which directly influences the biological effectiveness of the product applied (Maciel et al., 2017). On the other hand, increasing the size of the spray is an effective way to reduce the percentage of drift, especially in regions nearest the crop (Bueno et al., 2017). However, larger droplets

Table 2. Percentage of spray volume containing droplets smaller than $100 \mu \mathrm{m}$ of spray nozzles obtained with the laser particle analyzer in the pressures of $138,207,276,345$, and $414 \mathrm{kPa}$.

\begin{tabular}{llccccc}
\hline \multirow{2}{*}{ Equipment } & & \multicolumn{5}{c}{ V $<100(\%)$} \\
\cline { 2 - 7 } & \multicolumn{5}{c}{ Nozzsure $(\mathrm{kPa})$} \\
\cline { 2 - 6 } & Nozle & 138 & 207 & 276 & 345 & 414 \\
\hline \multirow{3}{*}{ Spraytec } & FC3D 100-02 & $3.81^{\mathrm{b}}$ & $8.81^{\mathrm{ab}}$ & $11.07^{\mathrm{b}}$ & $17.90^{\mathrm{b}}$ & $20.11^{\mathrm{b}}$ \\
& VP 110-02 & $8.40^{\mathrm{a}}$ & $10.61^{\mathrm{a}}$ & $17.50^{\mathrm{a}}$ & $22.44^{\mathrm{a}}$ & $26.39^{\mathrm{a}}$ \\
& TR 110-02 & $4.27^{\mathrm{b}}$ & $8.38^{\mathrm{ab}}$ & $15.16^{\mathrm{ab}}$ & $21.36^{\mathrm{a}}$ & $23.98^{\mathrm{ab}}$ \\
& TT 110-02 & $4.48^{\mathrm{b}}$ & $4.14^{\mathrm{b}}$ & $4.48^{\mathrm{c}}$ & $5.65^{\mathrm{c}}$ & $5.76^{\mathrm{c}}$ \\
\hline
\end{tabular}

Values followed by the same letter within the same column are not significantly different at $5 \%$ probability $(\mathrm{p}<0.05)$. 

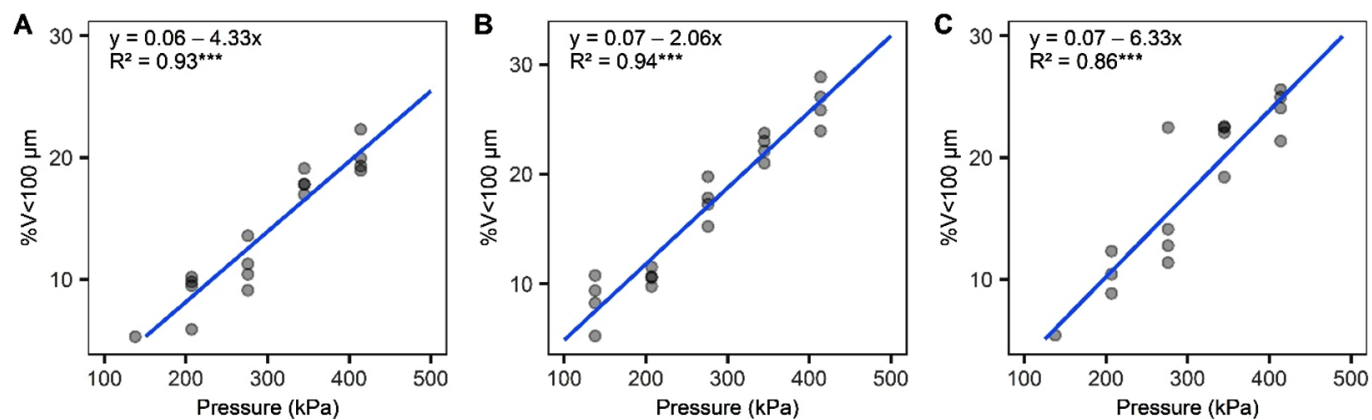

Figure 2. Estimates of the percentage of spray volume containing droplets smaller than $100 \mu \mathrm{m}$ as a function of the working pressure: (A) FC3D 100-02; (B) VP 110-02; and (C) TR 110-02.

(from 500 to $600 \mu \mathrm{m}$ ) can cause spray run-off; thus, the characteristics of the target surface must be considered (Massola et al., 2018). Besides that, one of the most complex issues applying phytosanitary products is related to the balance in obtaining a droplet size capable of generating good control and with less drift risk.

The analysis of the relative amplitude (Span) showed significant differences between the spray nozzles evaluated. The higher the Span value, the greater is the size range of the droplets produced. Also, for traditional nozzles that operate with hydraulic pressure, the formation of droplets is quite uneven, and their size is extremely uneven, often hindering an efficient application.

The FC3D 100-02 nozzle showed a Span variation from 1.30 to 1.75 for the evaluated pressures (138 to $414 \mathrm{kPa}$ ) (Table 3). The greater homogeneity of the droplets found in the lower pressure can be an important ally for obtaining a high-quality application and also for reducing the potential risk of drift. However, it is necessary to know the nozzle manufacturer's recommendations to ascertain the pressure range indicated for each model. The VP and TR 110-02 models presented the lower Span values under the pressure of $414 \mathrm{kPa}$ when compared to the other nozzles. However, these nozzles tend to produce fine to very fine droplets, and under higher pressures, they can produce a high percentage of droplets subject to drift, which could compromise the quality of the spray.

The TT 110-02 nozzle showed a tendency of reducing the relative amplitude of the droplets up to the $345 \mathrm{kPa}$ (Figure 3). For the same nozzle, the Span values ranged from 2.09 to 1.54 , corroborating the results reported by Cunha et al. (2010), which obtained a value of 1.74 for the same nozzle when subjected to a pressure of $276 \mathrm{kPa}$. Conversely, for the FC3D 100-02 model, the Span increased linearly with the increase of pressure. Similar results were found by Cunha et al. (2004) when using flat fan nozzles. Sasaki et al. (2016) also reported an increase in the Span index after applying higher pressures (up to $500 \mathrm{kPa}$ ) to the nozzles AI30070-015VP and AI3070-02VP. To obtain a

Table 3. Span index of the spray nozzles obtained with the laser particle analyzer in the pressures of $138,207,276,345$, and $414 \mathrm{kPa}$.

\begin{tabular}{llccccc}
\hline \multirow{2}{*}{ Equipment } & & \multicolumn{5}{c}{ Span } \\
\cline { 3 - 7 } & & \multicolumn{5}{c}{ Pressure (kPa) } \\
\hline \multirow{3}{*}{ Nozzle } & 138 & 207 & 276 & 345 & 414 \\
\hline \multirow{3}{*}{ Spraytec } & FC3D 100-02 & $1.30^{\mathrm{b}}$ & $1.46^{\mathrm{b}}$ & $1.56^{\mathrm{a}}$ & $1.60^{\mathrm{a}}$ & $1.75^{\mathrm{a}}$ \\
& VP 110-02 & $1.84^{\mathrm{a}}$ & $1.26^{\mathrm{c}}$ & $1.15^{\mathrm{b}}$ & $1.17^{\mathrm{c}}$ & $1.17^{\mathrm{b}}$ \\
& TR 110-02 & $1.52^{\mathrm{b}}$ & $1.28^{\mathrm{bc}}$ & $1.37^{\mathrm{ab}}$ & $1.28^{\mathrm{bc}}$ & $1.27^{\mathrm{b}}$ \\
& TT 110-02 & $2.09^{\mathrm{a}}$ & $1.73^{\mathrm{a}}$ & $1.58^{\mathrm{a}}$ & $1.54^{\mathrm{ab}}$ & $1.60^{\mathrm{a}}$ \\
\hline
\end{tabular}

Values followed by the same letter within the same column are not significantly different at $5 \%$ probability $(\mathrm{p}<0.05)$. 

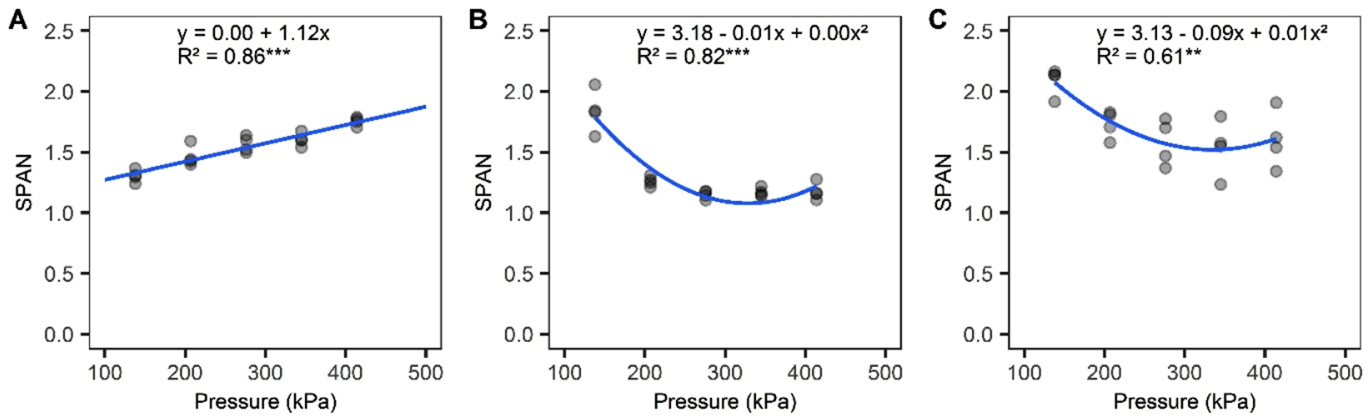

Figure 3. Estimates of the SPAN index as function of the working pressure: (A) FC3D 100-02; (B) VP 110-02; and (C) TT 110-02.

high-quality spray, better nozzle performance is required, especially regarding the homogeneity of the droplet spectrum (Cunha et al., 2004).

Even though the Span values have varied over the evaluated pressure range, it is not always possible to find a trend in this index regarding changes in the working pressure. Czaczyk (2012), after evaluating the droplets spectrum of flat fan nozzles, reported Span values of 1.32, 1.23, and 1.54 when using pressures of 150,300 , and $450 \mathrm{kPa}$. These results reinforce the need for evaluating the specific behavior of each spray nozzle at different pressures to avoid inefficient field applications.

When choosing the most suitable spray nozzle for a given situation, those with greater homogeneity of the droplets should be preferred. This selection should take into account those nozzles with a higher percentage of droplets less prone to drift and allow good coverage of the target. Lastly, the success of the phytosanitary treatment in crops relies on the user being able to equate all these variables.

\section{Conclusion}

Under the conditions in which the tests were carried out, the results allowed the following conclusions: (1) the spray nozzles models and the working pressure had a direct effect on the droplet size; (2) there were no significant differences between the TR 110-02 and VP 110-02 models for the percentage of spray volume containing droplets smaller than $100 \mu \mathrm{m}$ neither for the VMD; and (3) the increase of pressure resulted into an increasing linear effect on the Span index for the FC3D 100-02 nozzle.

\section{Acknowledgements}

This study was partially financed by the Coordenação de Aperfeiçoamento de Pessoal de Nível Superior (CAPES, Coordination for the Improvement of Higher Education Personnel) Finance Code 001, and by the Conselho Nacional de Desenvolvimento Científico e Tecnológico (CNPq, The Brazilian National Council for Scientific and Technological Development).

\section{Literature Cited}

Alvarenga, C.B.; Teixeira, M.M.; Zolnier, S.; Sasaki, R.S.; Rinaldi, P.C.N.

2013. Controle automático do espectro de gotas de pulverizador hidropneumático em função do déficit de pressão de vapor d’água no ar. Pesquisa Agropecuária Tropical, 43(1): 26-33.

Arvidsson, T.; Bergström, L.; Kreuger, J.

2011. Spray drift as influenced by meteorological and technical factors. Pest Management Science, 67(5): 586-598.

Balsari, P.; Gil, E.; Marucco, P.; Van De Zande, J.C.; Nuyttens, D.; Herbst, A.; Gallart, M.

Field-crop-sprayer potential drift measured using test bench: Effects of boom height and nozzle type. Biosystems Engineering, 154: 3-13.
Bueno, M.R.; Cunha, J.P.A.R.; De Santana, D.G.

2017. Assessment of spray drift from pesticide applications in soybean crops. Biosystems Engineering, 154: 35-45.

Camara, F.T.; Santos, J.L.; Silva, E.A.; Ferreira, M.D.C.

2008. Distribuição volumétrica e espectro de gotas de bicos hidráulicos de jato plano de faixa expandida XR11003. Engenharia Agrícola, 28(4): 740-749.

Cunha, J.P.A.R.; Bueno, M.R.; Ferreira, M.C.

2010. Espectro de gotas de pontas de pulverização com adjuvantes de uso agrícola. Planta Daninha, 28: 1153-1158.

Cunha, J.P.A.R.; Marques, R.S.; Alves, G.S.

Deposição da calda na cultura da soja em função de diferentes pressões de trabalho e pontas de pulverização. Revista Ceres, 63(6): 761-768. 
Cunha, J.P.A.R.; Silva, R.A.M.; Olivet, J.J.

Nozzle and spray volume evaluation on soybean (Glycine max (L.) Merrill) fungicide application. Revista La Facultad de Agronomia, 28(3): 344-359.

Cunha, J.P.A.R.; Teixeira, M.M.; Vieira, R.F.; Fernandes, H.C.; Coury, J.R.

2004. Espectro de gotas de bicos de pulverização hidráulicos de jato plano e de jato cônico vazio. Pesquisa Agropecuária Brasileira, 39: 977-985.

Cunha, J.P.A.R.; Teixeira, M.M.; Coury, J.R.; Ferreira, L.R. 2003. Avaliação de estratégias para redução da deriva de agrotóxicos em pulverizações hidráulicas. Planta Daninha, 21(2): 325-332.

Czaczyk, Z.

2012. Spray classification for selected flat fan nozzles. Journal of Plant Protection Research, 52(1): 180-183.

Dorneles, A.B.; Bottega, E.L.; Oliveira, Z.B.; Knies, A.E.; Silva, C.M.; Souza, I.J.

2019: Uso de diferentes pontas de pulverização no controle de doenças no trigo. Ciência e Natura, 40: 11-17.

Ferguson, J.C.; Chechetto, R.G.; Adkins, S.W.; Hewitt, A. J.;

Chauhan, B.S.; Kruger, G.R.; O'donnell, C.C.

2018. Effect of spray droplet size on herbicide efficacy on four winter annual grasses. Crop Protection, 112: 118-24.

Gandolfo, M.A.; Carvalho, F.K.; Chechetto, R.G.; Gandolfo, U.D.; De Moraes, E.D.

Effect of working pressure at different spray nozzles on drift quantification in wind tunnel. Engenharia Agrícola, 34(1): 66-73.

ISO. ISO 5682-1.

2017. Equipment for crop protection -Spraying equipmentPart 1: test methods for sprayer nozzles. $35 \mathrm{p}$.

Lopes, L.L.; Reis, E.F.

2020.Spectrum of spray droplets with different nozzles and adjuvants. Revista Brasileira de Ciências Agrárias, 15: 1-6.

Maciel, C.F.S.; Teixeira, M.M.; Fernandes, H.C.; Vitória,

E.L.; Cecon, P.R.

Distribuição volumétrica e espectro de gotas das pontas hidráulicas LD 11002 e MAG-2. Revista Engenharia na Agricultura - REVENG, 25: 183-199.
Maciel, C.F.S.; Teixeira, M.M.; Fernandes, H.C.; Zolnier, S.; Cecon, P.R.

2016. Droplet spectrum at different vapour pressure deficits. Revista Ciência Agronômica, 49(3): 430-436.

Marangoni Junior, A.; da Costa Ferreira, M.

2019. Influence of working pressure and spray nozzle on the distribution of spray liquid in manual backpack sprayers. Arquivos do Instituto Biológico, 86: 1-9.

Martini, A.T.; Avila, L.A.; Camargo, E.R.; Moura, D.S.; Marchezan, M.G.; Pivetta, A.P.

2015. Influência de adjuvantes e pontas de pulverização na deriva de aplicação do glyphosate. Planta Daninha, 33(2): 375-386.

Massola, M.P.; Holtz, V.; de O. Martins, M.P.; da S. Umbelino,

A.; dos Reis, E.F.

2018. Spray volume distribution pattern and droplet size spectrum from ceramic nozzles Avaliacao da distribuicao volumetrica e do espectro de gotas produzidos por pontas ceramicas. Revista Brasileira de Engenharia Agrícola e Ambiental, 22(11): 804-809.

Nuyttens, D.; Baetens, K.; De Schampheleire, M.; Sonck, B. 2007. Effect of nozzle type, size and pressure on spray droplet characteristics. Biosystems Engineering, 97: 333-345.

Nuyttens, D.; De Schampheleire, M.; Verboven, P.; Brusselman,

E.; Dekeyser, D.

2009. Droplet size and velocity characteristics of agricultural sprays. Transactions of ASABE, 52: 1471-1480.

Sasaki, R.S.; Teixeira, M.M.; Maciel, C.F.S.; Alvarenga, C.B.;

Forastiere, P.R.

2016. Espectro das gotas produzidas por pontas de jato plano duplo defasado com indução de ar. Revista Engenharia na Agricultura - REVENG, 24. 211-218.

Viana, R.G.; Ferreira, L.R.; Ferreira, M.C.; Teixeira, M.M.;

Rosell, J.R.; Tuffi, S.L.D.; Machado, A.F.L.

2010. Volumetric Distribution and Droplet Spectrum by Low Drift Spray Nozzles. Planta Daninha, 28(2): 439-446. 
